https://doi.org/10.18778/1427-9711.13.03

Arkadiusz Niewiadomski, Łukasz Szubert

Katedra Geografii Fizycznej, Pracownia Gleboznawstwa i Geoekologii

Wydział Nauk Geograficznych, Uniwersytet Łódzki

Artykuł wpłynął do redakcji 07.06.2014; po recenzjach zaakceptowany 19.11.2014

\title{
JAKOŚĆ GLEB WYBRANYCH OGRODÓW DZIALKOWYCH ŁODZI
}

\section{THE QUALITY OF SOILS OF SELECTED ALLOTMENT GARDENS IN LÓDŹ}

Praca prezentuje wyniki badań wybranych właściwości fizykochemicznych gleb ogrodów działkowych Łodzi. Przeanalizowano próbki z poziomów akumulacyjnych 15 ogrodów, zlokalizowanych głównie w sąsiedztwie dużych ciągów komunikacyjnych i obiektów przemysłowych. Dokonano charakterystyki substratu glebowego z uwzględnieniem czynników geologicznych, wpływających na genetyczną i jakościową wartość utworów glebowych w zakresie produkcji rolniczej. Autorzy zwrócili uwagę na zróżnicowanie właściwości gleb i dokonali porównania uzyskanych wyników z rezultatami analiz gleb ogrodów działkowych innych miast Polski. Stwierdzono, że badane gleby wykazują duże zdolności sorpcyjne i niewielki, w porównaniu z innymi miastami, stopień zanieczyszczenia gleb metalami ciężkimi (kadmem, chromem i miedzią). Ponadto podkreślono znaczny potencjał produkcyjny gleb ogrodów działkowych.

Słowa kluczowe: ogrody działkowe, gleby ogrodowe, właściwości gleb, Łódź

\section{Wprowadzenie}

Łódź, w porównaniu z innymi dużymi miastami w Polsce, posiada znaczny udział gleb zajętych przez tereny zieleni, wynoszący ponad 12\% ogólnej powierzchni miasta (Niewiadomski 2013). O ile na szczególną uwagę zasługują liczne parki oraz duży kompleks leśny usytuowany w granicach administracyjnych miasta, o tyle potencjał kryje się w formach zieleni osiedlowej, zwanych ogrodami działkowymi. W Łodzi istnieje ponad 100 obiektów Rodzinnych Ogrodów Działkowych (ROD). Z punktu widzenia lokalizacji większość z nich 
usytuowanych jest w sąsiedztwie osiedli mieszkaniowych i na obrzeżach miasta często wkomponowując się w lokalny krajobraz pól i zadrzewień strefy podmiejskiej. Ogrody usytuowane bliżej centrum sąsiadują natomiast $\mathrm{z}$ ciągami komunikacyjnymi i nierzadko dużymi zakładami przemysłowymi, wywierającymi wpływ na stan i jakość gleb oraz uprawianą roślinność. Wśród głównych zagrożeń oddziaływania miasta na tereny zieleni, a w tym w szczególności na ogrody działkowe, służące w znakomitej większości przypadków produkcji biomasy konsumpcyjnej, wymienia się metale ciężkie oraz inne rodzaje zanieczyszczeń, takich jak związki siarki, węgla czy azotu (Moir, Thornton 1989; Chodak $i$ in. 1995; Wegelin i in. 1995; Hursthouse i in. 2004; Jankiewicz i in. 2004; Bielińska 2006).

Postulaty likwidacji Rodzinnych Ogrodów Działkowych i przejęcia na rzecz lokalnych władz zajmowanych przez nie gruntów, często bardzo atrakcyjnych z inwestycyjnego punktu widzenia, spowodowały wzrost zainteresowania tymi terenami. Biorąc pod uwagę aspekt społeczny, należy uwzględnić mnogość funkcji terenów ROD-ów, jak choćby: rekreacyjnej, estetycznej, zdrowotnej, izolacyjnej, a w szczególności ekologicznej i produkcyjnej (Niewiadomski 2013). Ta ostatnia jest wyjątkiem w skali przestrzeni miejskiej i reprezentowana jest, poza terenami ogrodów działkowych, jedynie przez ogródki przydomowe lub tereny rolnicze peryferii miast. Ogrody działkowe stanowią ponadto ważny element struktury krajobrazu miejskiego, warunkujący jego harmonię. Poza tym wśród terenów zurbanizowanych są jednymi z niewielu obszarów przyrodniczo aktywnych.

\section{Materiał i metody}

Badania terenowe przeprowadzono wiosną i latem 2013 r. na obszarze 15 ogrodów działkowych, których lokalizację i podstawową charakterystykę przedstawia rys. 1 i tab. 1.

Wybór ogrodów uwarunkowano lokalizacją. Do badań wytypowano w większości ROD-y szczególnie narażone na negatywne oddziaływanie związane z immisją zanieczyszczeń komunikacyjnych i przemysłowych. Pod uwagę wzięto bliskość dróg o dużym natężeniu ruchu oraz obecność zakładów przemysłowych posiadających emitory zanieczyszczeń gazowych i pyłowych. Tłem chemicznym na obszarze miasta był ROD Ciżemka, zlokalizowany przy spokojnym osiedlu Radogoszcz Wschód, w sąsiedztwie Lasu Łagiewnickiego i w oddaleniu od dużych zakładów przemysłowych i dróg.

Próby gleb pobrano $\mathrm{z}$ wierzchniej części profilu z głębokości $0-15 \mathrm{~cm}$. Pobierano je z 3 działek na terenie danego ogrodu. W przypadku każdej działki pobór następował z 2-3 punktów w miejscach przygotowanych pod nasadzenia warzyw. Każdorazowo z terenu ogrodu pobierano zatem 6-9 próbek pojedynczych o masie około $200 \mathrm{~g}$ każda. Próby pobrano z powierzchni, których 


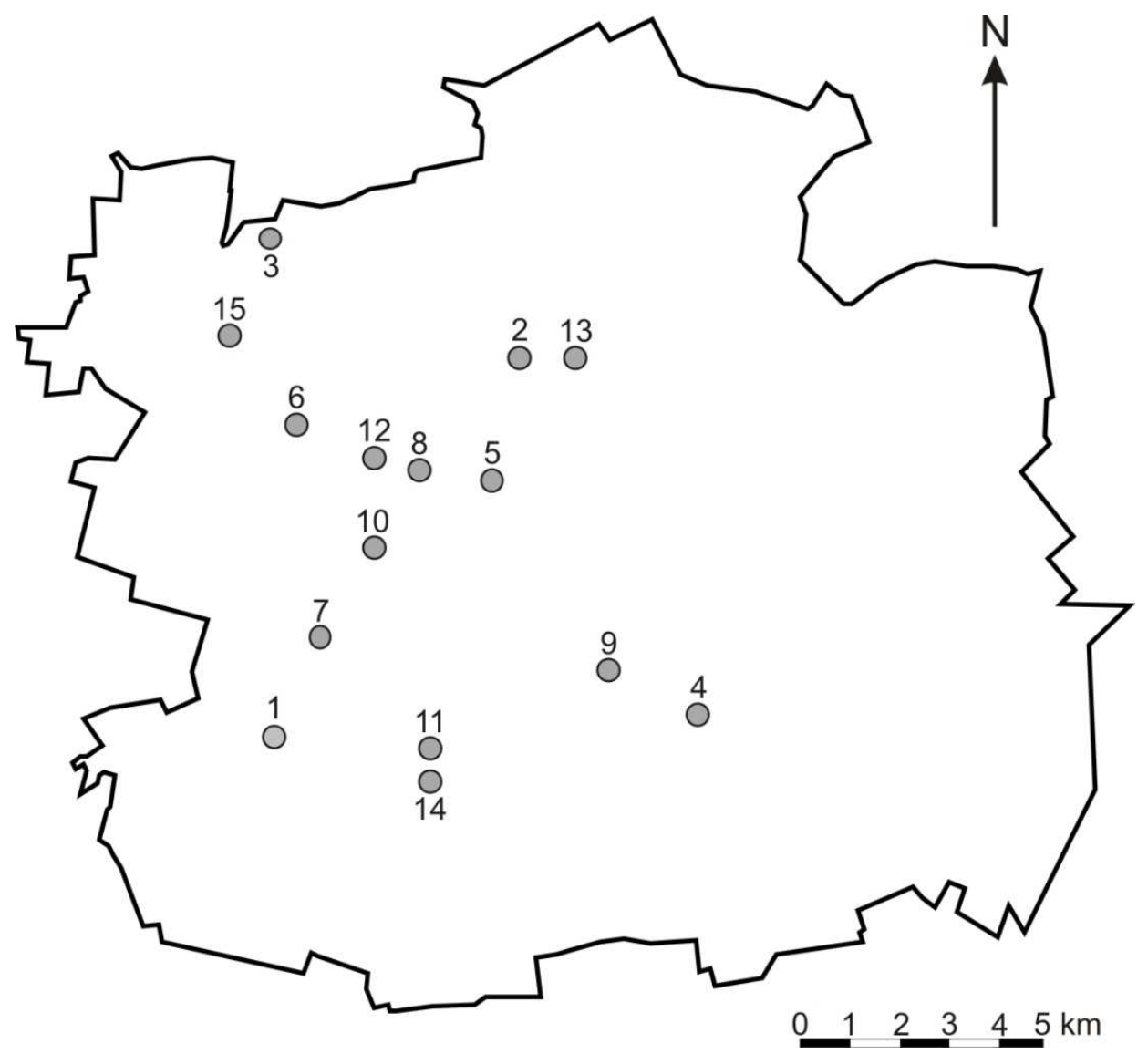

Rys. 1. Lokalizacja badanych ogrodów działkowych na terenie Łodzi ${ }^{1}$

Fig. 1. Location of studied allotment gardens in Łódź

właściciele deklarowali brak nawożenia mineralnego w danym roku. Niektóre z powierzchni wzbogacone były jedynie domowymi metodami np. w skorupki jaj kurzych, korę drzew lub nawóz organiczny, zazwyczaj w niewielkiej ilości. Pobrane próby uśredniono dla danego ogrodu przez wymieszanie. Każda z prób została następnie wysuszona $\mathrm{w}$ temperaturze pokojowej, a następnie roztarta w moździerzu. W tak przygotowanym materiale oznaczono:

- zawartości szkieletu glebowego metodą sitową z określeniem udziału szkieletu w próbie,

- skład granulometryczny metodą areometryczno-sitową Bouyoucosa-Casagrande'a w modyfikacji Prószyńskiego,

\footnotetext{
${ }^{1}$ Oznaczenia numerów ogrodów odpowiadają numeracji zamieszczonej w tab. 1.
} 
- odczyn $(\mathrm{pH})$ w wodzie i $1 \mathrm{~mol} \cdot \mathrm{dm}^{-3}$ roztworze $\mathrm{KCl}$ metodą potencjometryczną,

- zawartość węglanów $\left(\% \mathrm{CaCO}_{3}\right)$ metodą Scheiblera,

- zawartość węgla organicznego (Corg) metodą Tiurina,

- kwasowość hydrolityczną (Hh) metodą Kappena,

- sumę kationów zasadowych (S) metodą Kappena,

- zawartość kadmu, chromu i miedzi metodami absorpcyjnej spektrometrii atomowej (ASA).

Tab. 1

Powierzchnia ogólna, średnia powierzchnia i liczba działek badanych ogrodów działkowych

Total area, mean allotment area and amount of studied allotments

\begin{tabular}{|c|l|r|r|c|}
\hline $\begin{array}{c}\text { Nr } \\
\text { ogrodu }\end{array}$ & Nazwa ROD & $\begin{array}{c}\text { Powierzchnia } \\
\text { ogólna [ha] }\end{array}$ & $\begin{array}{c}\text { Liczba } \\
\text { działek }\end{array}$ & $\begin{array}{c}\text { Średnia } \\
\text { powierzchnia } \\
\text { działki [m²] }\end{array}$ \\
\hline 1 & Azalia & 13,05 & 337 & 387,2 \\
\hline 2 & Budowlani & 2,17 & 58 & 374,1 \\
\hline 3 & Ciżemka & 4,62 & 131 & 352,7 \\
\hline 4 & Dąbrowa & 11,43 & 272 & 420,2 \\
\hline 5 & Harnama & 1,74 & 90 & 193,3 \\
\hline 6 & Jarzębina & 5,99 & 153 & 391,5 \\
\hline 7 & Karolew & 7,12 & 161 & 442,2 \\
\hline 8 & Krokus & 3,40 & 73 & 465,8 \\
\hline 9 & Księży Młyn & 32,10 & 903 & 355,5 \\
\hline 10 & Mireckiego & 11,17 & 260 & 429,6 \\
\hline 11 & Nowe Rokicie & 4,38 & 132 & 331,8 \\
\hline 12 & Pod Wierzbami & 7,12 & 173 & 411,6 \\
\hline 13 & Reymonta & 16,37 & 323 & 506,8 \\
\hline 14 & Stokrotka & 3,18 & 93 & 341,9 \\
\hline 15 & Teofilek & 4,20 & 80 & 525,0 \\
\hline & Średnia & 8,54 & 216 & 395,3 \\
\hline
\end{tabular}

Źródło: opracowanie na podstawie danych pozyskanych ze strony $<$ http://lodz.pzd.pl/ogrody.aspx >.

Na podstawie wyników oznaczeń kwasowości hydrolitycznej i sumy kationów zasadowych wyliczono kationową pojemność sorpcyjną (T) badanych gleb. Ponadto wyliczono stopień wysycenia poziomu próchnicznego kationami o charakterze zasadowym (V), będący stosunkiem $\mathrm{S}$ do $\mathrm{T}$ przemnożonym przez $100 \%$. Grupę granulometryczną badanych utworów glebowych określono 
zgodnie z obowiązującymi podziałami Polskiego Towarzystwa Gleboznawczego. Stopień zanieczyszczenia gleb oznaczonymi metalami ciężkimi określono na podstawie wytycznych oceny zanieczyszczenia gleb wg zespołu A. Kabaty-Pendias (1995).

\section{Wyniki badań i dyskusja}

Łódzkie ROD-y stanowią ponad 2\% takich obiektów w skali całego kraju. Ich łączna powierzchnia przekracza 730 ha $(1,68 \%$ w skali Polski) i skupiają około 16500 działek (ponad 1,7\% w Polsce) $)^{2}$. Średnia powierzchnia statystycznego ogrodu wynosi 7,2 ha (zmienia się w zakresie od 1,32 ha w ROD Sielanka do 32,10 ha w ROD Księży Młyn). Średnia liczba działek w obrębie statystycznego ROD-u to 163, a średnia powierzchnia pojedynczej działki to prawie $443 \mathrm{~m}^{2}$ (dane ze strony <http://lodz.pzd.pl/ogrody.aspx>).

Podłoże geologiczne gleb ogrodów działkowych Łodzi stanowią, na obszarze niemal całego miasta, osady zlodowacenia Warty, głównie piaski wodnolodowcowe i gliny zwałowe. Pod względem genetycznym gleby analizowanych ROD-ów zbudowane są z piasków i spiaszczonych glin reprezentujących gleby bielicowe, rdzawe i brunatne (Ziomek, Iwańcz, Laskowski 2009). Gleby ogrodów działkowych są dodatkowo przekształcone w wierzchniej części profilu, co jest wynikiem intensywnego użytkowania i pielęgnacji. Biorąc pod uwagę bonitację gleb, reprezentują one kompleksy żytnie, przeważnie 5, 6 i 7 (Ziomek, Iwańcz, Laskowski 2009). Badanie składu granulometrycznego gleb wykazało, że wszystkie analizowane utwory to piaski (tab. 2).

Pod względem udziału części szkieletowych 11 prób stanowiły utwory bezszkieletowe. Tylko 4 (Ciżemka, Dąbrowa, Mireckiego i Nowe Rokicie) należały do utworów słabo szkieletowych. Wśród ziaren frakcji piaszczystej dominują piaski drobne. Znaczny udział stanowią także piaski średnioziarniste, najmniejszy zaś grube. Udział frakcji pylastej w analizowanych glebach był niewielki i nie przekraczał $21 \%$. Utwory wykazały minimalną zawartość frakcji ilastej, co jest typowe dla utworów wodnolodowcowych i eolicznych. 7 prób glebowych należało do grupy granulometrycznej piasków luźnych, po 4 do piasków słabogliniastych i gliniastych. Pod względem uziarnienia gleby wykazały niewielkie różnice.

Większość badanych gleb wykazała typową dla hortisoli właściwość - znaczny udział materii organicznej (tab. 3). Średnia zawartość próchnicy wyniosła $3,99 \%$. Jest to wynikiem intensywnej uprawy, stosowania nawożenia orga-

\footnotetext{
${ }^{2}$ Określono na podstawie danych pozyskanych ze stron <http://lodz.pzd.pl/ogrody. aspx> oraz http://pzd.pl/artykuly/4576/111/Komunikat-o-stanie-posiadania-PZD-na-dzi en-31-12-2011-na-podstawie-ankiet-stanu-organizacyjnego-przekazanych-przez-OZPZD. html; dostęp 26.05.2014.
} 
nicznego i dużej dbałości o stan pokrywy glebowej. Jest to typowe dla obszarów uprawnych, na których po jesienno-zimowym odpoczynku odnawiają się zasoby próchnicy, ulegające zubożeniu w procesie rozwoju roślinności w trakcie cyklu wegetacyjnego. Podobną, a w niektórych przypadkach nawet większą zawartość materii organicznej odnotowano $\mathrm{w}$ przypadku innych miast w Polsce, np. Wrocławia, Gdańska i Kielc (Bielińska 2006; Oleśków 2007; Bielicka i in. 2009; Świercz, Sykała 2009).

Tab. 2

Skład granulometryczny analizowanych gleb

Granulometric composition of analysed soils

\begin{tabular}{|c|c|c|c|c|c|c|c|c|c|c|}
\hline \multirow{3}{*}{$\begin{array}{c}\text { Nazwa } \\
\text { ROD }\end{array}$} & \multicolumn{9}{|c|}{ Zawartość frakcji [mm] } & \multirow{3}{*}{$\begin{array}{l}\text { Grupa } \\
\text { granu- } \\
\text { lome- } \\
\text { tryczna }\end{array}$} \\
\hline & \multirow{2}{*}{\begin{tabular}{|c|}
$\begin{array}{c}\text { szkie- } \\
\text { letu }\end{array}$ \\
$>2$ \\
\end{tabular}} & \multicolumn{5}{|c|}{ piasku } & \multicolumn{2}{|c|}{ pyłu } & \multirow{2}{*}{\begin{tabular}{|c|} 
iłu \\
$<0,002$ \\
\end{tabular}} & \\
\hline & & $2-1$ & $1-0,5$ & $\begin{array}{c}0,5 \\
-0,25 \\
\end{array}$ & $\begin{array}{l}0,25 \\
-0,1 \\
\end{array}$ & $\begin{array}{c}0,1 \\
-0,05 \\
\end{array}$ & $\begin{array}{c}0,05 \\
-0,02 \\
\end{array}$ & \begin{tabular}{|c|}
0,02 \\
$-0,002$ \\
\end{tabular} & & \\
\hline Azalia & 3 & 5 & 9 & 21 & 51 & 8 & 3 & 3 & 0 & $\mathrm{pl}$ \\
\hline Budowlani & 3 & 4 & 9 & 15 & 33 & 21 & 11 & 7 & 0 & $\mathrm{pg}$ \\
\hline Ciżemka & 5 & 2 & 10 & 24 & 54 & 6 & 1 & 3 & 0 & $\mathrm{pl}$ \\
\hline Dąbrowa & 6 & 2 & 11 & 20 & 38 & 18 & 6 & 5 & 0 & ps \\
\hline Harnama & 3 & 4 & 7 & 13 & 32 & 23 & 12 & 9 & 0 & $\mathrm{pg}$ \\
\hline Jarzębina & 3 & 2 & 10 & 18 & 47 & 16 & 2 & 5 & 0 & $\mathrm{pl}$ \\
\hline Karolew & 4 & 4 & 9 & 19 & 46 & 13 & 3 & 6 & 0 & $\mathrm{pl}$ \\
\hline Krokus & 3 & 3 & 8 & 19 & 45 & 15 & 5 & 3 & 2 & ps \\
\hline Księży Młyn & 3 & 2 & 11 & 19 & 38 & 23 & 3 & 3 & 1 & $\mathrm{pl}$ \\
\hline Mireckiego & 5 & 4 & 8 & 19 & 42 & 17 & 6 & 4 & 0 & $\mathrm{pl}$ \\
\hline $\begin{array}{l}\text { Nowe } \\
\text { Rokicie } \\
\end{array}$ & 6 & 12 & 10 & 16 & 35 & 12 & 5 & 7 & 3 & $\mathrm{pg}$ \\
\hline $\begin{array}{l}\text { Pod } \\
\text { Wierzbami }\end{array}$ & 3 & 1 & 10 & 21 & 47 & 12 & 5 & 3 & 1 & $\mathrm{pl}$ \\
\hline Reymonta & 3 & 3 & 11 & 14 & 33 & 23 & 10 & 5 & 1 & $\mathrm{pg}$ \\
\hline Stokrotka & 4 & 6 & 9 & 15 & 40 & 19 & 3 & 5 & 4 & ps \\
\hline Teofilek & 2 & 3 & 9 & 20 & 44 & 12 & 8 & 4 & 0 & ps \\
\hline
\end{tabular}

Źródło: opracowanie własne.

Pod względem odczynu wszystkie gleby należały do utworów obojętnych (tab. 3). Co więcej, zróżnicowanie $\mathrm{pH}$ w obrębie analizowanych powierzchni było bardzo małe i wahało się w zakresie 6,62-7,02 dla pH w $\mathrm{KCl}$ i 6,52-7,00 w wodzie destylowanej. Wysokie wartości odczynu gleb ogrodowych są wynikiem regularnego, corocznego nawożenia mineralnego związkami wapnia. Większość działkowców potwierdzała stosowanie wapnowania gleb w latach 
poprzednich. Jest to korzystne dla roślin - zwiększa dostępność niektórych makro- i mikroelementów, a ponadto ogranicza migrację niektórych rodzajów zanieczyszczeń, a przede wszystkim metali ciężkich, których mobilność ściśle związana jest z odczynem gleb (Chodak i in. 1995; Kabata-Pendias i in. 1995; Bielicka i in. 2009).

Tab. 3

Właściwości fizykochemiczne badanych gleb

Physiochemical properties of analysed soils

\begin{tabular}{|c|c|c|c|c|c|c|c|c|c|}
\hline \multirow[b]{2}{*}{ Nazwa ROD } & \multirow[b]{2}{*}{$\%$ Corg } & \multirow[b]{2}{*}{$\% \mathrm{P}$} & \multicolumn{2}{|c|}{ Odczyn } & \multirow{2}{*}{$\begin{array}{c}\% \\
\mathrm{CaCO}_{3}\end{array}$} & \multicolumn{4}{|c|}{ Właściwości sorpcyjne } \\
\hline & & & $\begin{array}{c}\mathrm{pH} \\
\mathrm{w} \mathrm{H}_{2} \mathrm{O}\end{array}$ & $\begin{array}{c}\mathrm{pH} \\
\mathrm{w} \mathrm{KCl}\end{array}$ & & $\mathrm{Hh}$ & S & $\mathrm{T}$ & V \\
\hline Azalia & 2,83 & 4,88 & 6,62 & 6,87 & 0,00 & 3,47 & 13,56 & 19,35 & 86,63 \\
\hline Budowlani & 1,90 & 3,27 & 6,72 & 6,91 & 0,20 & 2,08 & 24,53 & 26,61 & 92,21 \\
\hline Ciżemka & 1,51 & 2,61 & 7,00 & 6,68 & 0,00 & 3,12 & 5,60 & 8,72 & 64,22 \\
\hline Dąbrowa & 1,64 & 2,82 & 6,98 & 6,62 & 0,00 & 3,38 & 14,00 & 17,38 & 80,55 \\
\hline Harnama & 3,02 & 5,20 & 6,82 & 6,57 & 0,00 & 2,60 & 32,40 & 35,00 & 92,57 \\
\hline Jarzębina & 2,28 & 3,92 & 6,87 & 6,68 & 0,00 & 2,34 & 4,00 & 6,34 & 63,09 \\
\hline Karolew & 2,50 & 4,32 & 6,64 & 6,86 & 0,20 & 1,82 & 27,70 & 29,52 & 93,80 \\
\hline Krokus & 3,34 & 5,76 & 6,78 & 6,65 & 0,00 & 2,60 & 8,20 & 10,80 & 75,93 \\
\hline Księży Młyn & 2,34 & 4,04 & 6,83 & 6,72 & 0,00 & 1,56 & 30,20 & 31,76 & 95,09 \\
\hline Mireckiego & 2,33 & 4,01 & 6,67 & 6,65 & 0,00 & 3,12 & 22,00 & 25,12 & 87,58 \\
\hline $\begin{array}{l}\text { Nowe } \\
\text { Rokicie } \\
\end{array}$ & 2,75 & 4,73 & 7,02 & 6,73 & 0,00 & 1,30 & 43,80 & 45,10 & 97,12 \\
\hline $\begin{array}{l}\text { Pod } \\
\text { Wierzbami }\end{array}$ & 1,87 & 3,22 & 6,70 & 6,52 & 0,00 & 2,60 & 13,20 & 15,80 & 83,54 \\
\hline Reymonta & 3,14 & 5,40 & 6,97 & 6,63 & 0,00 & 2,08 & 43,00 & 45,08 & 95,39 \\
\hline Stokrotka & 1,72 & 2,97 & 7,00 & 6,67 & 0,00 & 1,82 & 34,60 & 36,42 & 95,00 \\
\hline Teofilek & 1,55 & 2,67 & 6,83 & 7,00 & 0,00 & 3,21 & 11,27 & 14,47 & 76,85 \\
\hline Średnia & 2,31 & 3,99 & 6,83 & 6,72 & 0,00 & 2,47 & 21,87 & 24,50 & 85,30 \\
\hline
\end{tabular}

Źródło: opracowanie własne.

Zawartość węglanu wapnia $\mathrm{w}$ badanych glebach była minimalna (poniżej $0,1 \% \mathrm{CaCO}_{3}$, której to wartości z uwagi na możliwy błąd pomiarowy nie wzięto pod uwagę), a znakomita większość analizowanych ogrodów nie wykazała jego obecności. Jak wspomniano we wprowadzeniu, wybrano powierzchnie, na których w danym roku nie prowadzono nawożenia wapniowego. Lekki skład granulometryczny gleb powoduje wymycie związków wapnia w głąb profilu, reszta zaś bioakumulowana jest przez rośliny. $\mathrm{W}$ trakcie prowadzenia badań terenowych stwierdzono, że w przypadku gleb, w których na niewielkiej głębokości pojawiała się glina (40-60 cm od powierzchni terenu), węglan wapnia 
ulegał nagromadzeniu nad stropem warstw gliniastych, co potwierdzono przy użyciu $10 \%$ roztworu kwasu solnego. Udział węglanu wapnia w przypadku gleb ogrodowych wykazuje dużą zmienność w ciągu cyklu wegetacyjnego w zależności od momentu nawożenia, potrzeb roślin i wspomnianego uziarnienia gleb.

Analizowane utwory glebowe odznaczały się zróżnicowanymi właściwościami sorpcyjnymi. Właściwości te mają istotne znaczenie w zakresie zaopatrzenia roślin w składniki pokarmowe. W glebach wykazujących dużą zdolność sorbowania związków mineralnych składniki dostarczane $\mathrm{z}$ nawozami nie są wymywane w głąb profilu glebowego i dalej do wód gruntowych, lecz uruchamiane stopniowo z kompleksu sorpcyjnego w okresie rozwoju roślin. Wszystkie gleby cechowały się niewielką kwasowością hydrolityczną w zakresie od 1,56 do $3,47 \mathrm{cmol}(+) \cdot \mathrm{kg}^{-1}$ przy średniej wynoszącej $2,47 \mathrm{cmol}(+) \cdot \mathrm{kg}^{-1}$. Kwasowość ta pozwala na określenie koniecznej dawki nawozów wapniowych służących do neutralizacji substancji kwaśnych, głównie związków wodoru i glinu. Suma kationów metali o charakterze zasadowym przyjmowała znacznie wyższe wartości, za wyjątkiem gleb w ogrodach Jarzębina, Ciżemka i Krokus. Na ich udział największy wpływ ma zawartość wapnia, magnezu, sodu i potasu. Stanowią one bowiem ważne źródło substancji pokarmowych. Obecność dwuwartościowych kationów zasadowych w kompleksie sorpcyjnym gleby wpływa korzystnie na właściwości fizyczne, w tym głównie na tworzenie korzystnej, gruzełkowatej struktury. Ponadto poprawiają one właściwości wodne, gdyż niektóre z tych związków są lepiszczem naturalnie luźnego substratu glebowego. Poprawiają przez to zdolność zatrzymywania wody zwłaszcza w przypadku gleb piaszczystych, w których właściwość ta nie występuje. Najwyższe wartości sumy kationów sięgające ponad $40 \mathrm{cmol}(+) \cdot \mathrm{kg}^{-1}$ stwierdzono w przypadku ROD-ów Nowe Rokicie i Reymonta, choć w porównaniu z pojemnością sorpcyjną bogatych $\mathrm{w}$ związki wapnia gleb $\mathrm{z}$ rejonu Zabrza, Bytomia czy Białej Podlaskiej są on kilkukrotnie mniejsze (Wójcikowska-Kapusta 2007). W ogrodach działkowych sorpcja determinowana jest obecnością materii organicznej, której udział w przypadku hortisoli jest zazwyczaj wysoki. Kationowa pojemność sorpcyjna badanych gleb wykazała dużą zmienność w układzie przestrzennym. W przypadku ROD-ów Jarzębina i Ciżemka, gdzie wyniosła ona poniżej $9,00 \mathrm{cmol}(+) \cdot \mathrm{kg}^{-1}$, świadczy to o małej zdolności zatrzymywania składników pokarmowych i niewielkiej sorpcji wody. $\mathrm{W}$ efekcie może to powodować oddziaływanie zanieczyszczeń, które wnikają w glebę i przemieszczane są w profilu (Wójcikowska-Kapusta 2007). Potwierdza to także znikomy udział iłu koloidalnego w tych profilach. Na korzyść świadczy jedynie odczyn gleb i zawartość węgla organicznego. Kationowa pojemność sorpcyjna odgrywa kluczową rolę w migracji i biodostępności metali ciężkich. W glebach wykazujących wysoką zawartość metali (np. kadmu, ołowiu czy miedzi) duża pojemność sorpcyjna ogranicza ich wymywanie oraz transfer do łańcucha żywieniowego roślin uprawnych (Jankiewicz i in. 2004; 
Świercz, Sykała 2009). Wszystkie próbki gleb wykazały wysoki i bardzo wysoki (powyżej 60\%, a w większości powyżej 80\%) stopień wysycenia kompleksu sorpcyjnego kationami, co wpływa dodatnio na odporność gleb na ewentualne zmiany odczynu, a zwłaszcza zakwaszenie (Niewiadomski 2014).

Z uwagi na lokalizację analizowanych ogrodów działkowych i możliwy wpływ czynników degradujących przeprowadzono badanie zawartości trzech metali ciężkich - kadmu, chromu i miedzi (tab. 4). Kadm i chrom należą do pierwiastków toksycznych, których koncentracja w glebie wpływa negatywnie na ilość i skład mikrofauny glebowej (Jankiewicz i in. 2000). Mimo, iż wykazują one niewielki wpływ na rozwój roślin są bardzo szkodliwe dla zwierząt. Poza tym możliwa jest także migracja metali z gleb do roślin uprawnych przeznaczanych do bezpośredniej konsumpcji. Kadm jest stosunkowo intensywnie pobierany przez rośliny i łatwo transportowany poprzez system korzeniowy do wszystkich organów (Jankiewicz i in. 2000; Ociepa-Kubicka, Ociepa 2012). Chrom natomiast wykazuje dużą zdolność migracji w formie uwodnionej, a jego mobilność w glebie ściśle zależy od odczynu. Jest także pierwiastkiem kancerogennym, wykazującym bardzo negatywny wpływ na organizmy zwierzęce (Jankiewicz i in. 2000; Właśniewski, Hajduk 2012). Miedź jest pierwiastkiem niezbędnym dla roślin w niewielkiej ilości, gdyż wpływa na proces fotosyntezy i jest składnikiem wielu enzymów (Jankiewicz i in. 1999; Węglarzy 2007). Jej uwalnianie $\mathrm{z}$ gleby ściśle związane jest $\mathrm{z}$ odczynem. Im wartość $\mathrm{pH}$ jest wyższa tym reaktywność tego pierwiastka maleje. Jest trudniej rozpuszczalna, przez co ulega kumulacji głównie w wierzchniej warstwie gleby. Wchłonięta przez roślinę wykazuje oddziaływanie podobne do kadmu (Jankiewicz i in. 1999).

Jak wynika z przeprowadzonych badań, większość gleb ogrodów działkowych wykazuje podwyższoną zawartość kadmu i miedzi. Podobne wyniki w odniesieniu do ogrodów działkowych Łodzi uzyskał B. Jankiewicz z zespołem (1999, 2000, 2004). Niewielką zawartość metali ciężkich w ramach badań monitoringu środowiska glebowego stwierdzono również na innych terenach z obszaru miasta (Niedbała, Smolińska 2011). Ponadto badania zespołu B. Jankiewicza (2000) potwierdzają, że udział metali spada w miarę wzrostu odległości od ciągów komunikacyjnych. Należy zatem zwracać większą uwagę na oznaki zanieczyszczenia w przypadku tych właśnie pierwiastków, co najłatwiej obserwowalne jest $\mathrm{w}$ odniesieniu do kondycji roślinności. Zawartość kadmu i chromu w badanych glebach waha się w wąskich zakresach. Jedynie miedź wykazuje większe zróżnicowanie wartości - od 4,00 mg/kg suchej masy w ROD Ciżemka do 65,20 mg/kg w ROD Krokus. Co ciekawe, badania B. Jankiewicza i in. (1999) w ROD Nowe Rokicie wykazały nieco wyższe wyniki zawartości miedzi od uzyskanych. Prawdopodobnie są one efektem spadku wielkości emisji zanieczyszczeń ze źródeł przemysłowych w ciągu ostatnich kilkunastu lat. W przypadku kadmu brak zanieczyszczenia odnotowano tylko w ROD Ciżemka, zaś miedzi w czterech ogrodach - Azalia, Ciżemka, Dąbrowa i Jarzębina. 
Wysokie wartości odczynu badanych gleb ograniczają mobilność metali ciężkich, a co za tym idzie także ich przejście do form rozpuszczalnych (Jankiewicz i in. 2004; Węglarzy 2007; Bielicka i in. 2009). Dodatkowo na ograniczenie mobilności metali wpływa duża pojemność sorpcyjna gleb.

Tab. 4

Zawartość kadmu, chromu i miedzi w glebach ogrodów działkowych Łodzi

Content of cadmium, chromium and copper in soils of allotment gardens in Łódź

\begin{tabular}{|c|c|c|c|c|c|c|}
\hline \multirow{2}{*}{ Nazwa ROD } & \multicolumn{3}{|c|}{ Zawartość w [mg/kg] } & \multicolumn{3}{|c|}{$\begin{array}{c}\text { Stopień zanieczyszczenia } \\
\text { gleby* }\end{array}$} \\
\hline & $\mathrm{Cd}$ & $\mathrm{Cr}$ & $\mathrm{Cu}$ & $\mathrm{Cd}$ & $\mathrm{Cr}$ & $\mathrm{Cu}$ \\
\hline Azalia & 0,44 & 8,30 & 11,40 & I & 0 & 0 \\
\hline Budowlani & 0,61 & 11,20 & 16,60 & $\mathrm{I}$ & 0 & I \\
\hline Ciżemka & $<0,20 * *$ & $<4,00 * *$ & 4,00 & 0 & 0 & 0 \\
\hline Dąbrowa & 0,32 & 8,60 & 11,60 & I & 0 & 0 \\
\hline Harnama & 1,36 & 21,70 & 63,60 & II & I & II \\
\hline Jarzębina & 0,61 & 9,90 & 14,00 & I & 0 & 0 \\
\hline Karolew & $<0,20 * *$ & 9,90 & 20,60 & $\mathrm{I}$ & 0 & I \\
\hline Krokus & 0,89 & 16,40 & 65,20 & I & 0 & II \\
\hline Księży Młyn & 0,89 & 15,80 & 21,00 & I & 0 & I \\
\hline Mireckiego & 0,61 & 8,60 & 29,20 & I & 0 & I \\
\hline Nowe Rokicie & 0,56 & 16,40 & 34,60 & I & 0 & I \\
\hline Pod Wierzbami & 0,46 & 15,10 & 18,60 & I & 0 & I \\
\hline Reymonta & 0,79 & 17,80 & 37,60 & $\mathrm{I}$ & 0 & I \\
\hline Stokrotka & 0,63 & 12,80 & 20,60 & I & 0 & I \\
\hline Teofilek & 0,37 & 11,90 & 17,20 & I & 0 & $\mathrm{I}$ \\
\hline Średnia & 0,66 & 13,17 & 25,72 & - & - & - \\
\hline
\end{tabular}

* 0 - zawartość naturalna, I - zawartość podwyższona, II - słabe zanieczyszczenie.

** zawartość poniżej granicy oznaczalności metody.

Źródło: opracowanie własne.

Podkreślić należy, że nagła zmiana odczynu, np. wywołana zmianą formy użytkowania czy zagospodarowania terenu, mogłaby spowodować wzrost zagrożenia presją metali na gleby, a w szczególności na roślinność i tym samym zwiększyć stopień degradacji pokrywy glebowej. Tylko jeden ROD - Ciżemka wykazał naturalną zawartość wszystkich analizowanych metali. Świadczy to o braku wpływu czynników lokalizacyjnych na gleby tego ogrodu działkowego. Jest to uzasadnione $\mathrm{z}$ racji jego usytuowania $\mathrm{w}$ dużej odległości od centrum 
miasta i położenia w sąsiedztwie dwóch kompleksów leśnych oddalonych od osiedla mieszkaniowego. Ogród ten miał stanowić punkt odniesienia dla pozostałych ROD-ów, co potwierdziły przeprowadzone badania. W glebach żadnego z badanych ogrodów działkowych nie stwierdzono średniego, silnego czy bardzo silnego zanieczyszczenia oznaczonymi metalami. Najwyższe stopnie zanieczyszczenia stwierdzono względem kadmu i miedzi w ROD Harnama oraz miedzi w przypadku ROD Krokus. ROD Harnama, jako jedyny wykazał podwyższoną zawartość lub słabe zanieczyszczenie w przypadku wszystkich zmierzonych metali ciężkich. W przypadku tego ogrodu dwa czynniki lokalizacyjne silniej niż w przypadku pozostałych ROD-ów wpłynęły na jakość środowiska glebowego. Są to trzy ważne szlaki komunikacyjne: ulica Wojska Polskiego, Franciszkańska i Smugowa oraz bliskość dworca PKS i związany z nim intensywny ruch kołowy. Dodatkowym czynnikiem jest także mała powierzchnia ogrodu.

Uzyskane wyniki badań porównano $\mathrm{z}$ wynikami monitoringu gleb przeprowadzonego w 1996 r. w ramach projektu Atlas geochemiczny aglomeracji tódzkiej (Lis, Pasieczna 1998). Spośród 1127 prób glebowych pobranych z obszaru Łodzi i okolicznych jednostek osadniczych, tylko 5 reprezentowało ogrody działkowe. Autorzy nie podali, z których ogrodów pobrane zostały próby. Biorąc pod uwagę lokalizację ogrodów w przestrzeni miejskiej da się zauważyć, że podwyższona zawartość chromu w glebach ogrodów działkowych jest prawdopodobnie typowa właśnie dla tego typu obszarów. Autorzy Atlasu ponadnormatywną zawartość tego pierwiastka stwierdzili w rejonie ścisłego centrum miasta i miejsc dużej koncentracji infrastruktury drogowej. Ogólny brak zanieczyszczenia gleb ogrodów działkowych chromem, w porównaniu z dużą koncentracją tego pierwiastka $\mathrm{w}$ glebach, uzależniony jest miejscami poboru prób. Mała reprezentatywność obszarów ROD-ów w ramach przeprowadzonych badań monitoringowych uniemożliwia prawidłową interpretację wyników. Zbieżność wyników da się natomiast zaobserwować w odniesieniu do zawartości miedzi. Zarówno w przeprowadzonych badaniach, jak i w wynikach badań monitoringowych, zauważalne jest zanieczyszczenie miedzią poziomów wierzchnich gleb w okolicy centrum miasta (tu zlokalizowane są ROD-y Harnama, Krokus) oraz w sąsiedztwie dużych ciągów komunikacyjnych (większość ROD-ów, w których stwierdzono podwyższoną zawartość miedzi). Badania przeprowadzone przez J. Lisa i A. Pasieczną (1998) wskazują, że jedynie na peryferiach miasta zawartość metali ciężkich jest zbliżona do naturalnej, co potwierdzają wyniki koncentracji kadmu, chromu i miedzi uzyskane dla ROD Ciżemka, zlokalizowanego w północnej części miasta, w oddaleniu od wpływu czynników degradujących.

Porównując zawartość metali ciężkich $\mathrm{w}$ badanych ROD-ach na terenie Łodzi $\mathrm{z}$ zawartością metali ciężkich $\mathrm{w}$ ogrodach działkowych innych miast wyraźnie widać, że najgorsza sytuacja występuje na Górnym Śląsku (Mocek i in. 
1995; Bielińska, Mocek-Płóciniak 2010), gdzie koncentracja metali ciężkich jest zazwyczaj kilku, a nawet kilkunastokrotnie wyższa niż w Łodzi. Łódź wykazuje niższe zanieczyszczenie gleb metalami ciężkimi niż inne duże ośrodki miejskie, jak Kraków, Wrocław, Gdańsk czy Lublin, a także, co ciekawe, mniejsze miasta, jak Biała Podlaska czy Stalowa Wola (Bielińska 2006; Oleśków 2007; Bielicka i in. 2009). W przypadku małych miast powodem może być bliskość lokalizacji ogrodów względem drogowych i kolejowych ciągów komunikacyjnych oraz stref przemysłowych. Gleby ogrodów działkowych Łodzi są za to bardziej zanieczyszczone niż np. gleby podobnych terenów w Kielcach (Świercz, Sykała 2009) czy Rzeszowie (Właśniewski, Hajduk 2012), gdzie również zwrócono uwagę na kwestię wzrostu zawartości metali w obrębie ogrodów położonych w sąsiedztwie dużych ciągów komunikacyjnych.

\section{Wnioski}

1. Jakość gleb ogrodów działkowych Łodzi jest wynikiem posiadanych przez nie właściwości fizykochemicznych. Pod względem genetycznym gleby ogrodów działkowych Łodzi zbudowane są z materiału glacjalnego i fluwioglacjalnego, wykazują lekkie, piaszczyste uziarnienie, przez co charakteryzują się niewielką pojemnością sorpcyjną, dużą przepuszczalnością i przewiewnością.

2. Wartości pH analizowanych gleb oscylowało w granicach odczynu obojętnego, co jest korzystne dla produkcji roślinnej oraz ograniczenia wpływu zanieczyszczeń, zwłaszcza pod kątem mobilności metali ciężkich.

3. Badane gleby wykazały podwyższoną zawartość próchnicy glebowej, będącej efektem intensywnej gospodarki rolnej i prowadzenia szeregu zabiegów pielęgnacyjnych. Dzięki wysokiemu udziałowi materii organicznej gleby ogrodów działkowych są w stanie zapewnić roślinom zasób składników pokarmowych oraz wody, zwłaszcza w początkowym okresie ich rozwoju.

4. Duża sorpcja kationów, znacznie przewyższająca wartość kwasowości hydrolitycznej, zapewnia glebom ogrodów działkowych Łodzi odporność na zakwaszenie oraz prawidłowe funkcjonowanie mechanizmu odżywiania roślin. Pojemność sorpcyjna wraz z wysokimi wartościami pH ograniczają negatywny wpływ metali ciężkich i innych zanieczyszczeń.

5. Zawartość wybranych metali ciężkich cechowała się niewielkim zróżnicowaniem. Większość gleb wykazała podwyższoną zawartość kadmu i miedzi. Tylko w dwóch przypadkach (ROD-y Harnama i Krokus) stwierdzono słabe zanieczyszczenie gleb metalami.

6. Gleby ogrodów działkowych Łodzi w porównaniu z analogicznymi terenami innych miast Polski odznaczają się $\mathrm{w}$ większości niższym stopniem degradacji ze strony metali ciężkich. 


\section{LITERATURA}

Bielicka A., Ryłko E., Bojanowska I., 2009, Zawartość pierwiastków metalicznych w glebach $i$ warzywach z ogrodów dziatkowych Gdańska i okolic, „Ochrona Środowiska i Zasobów Naturalnych", 40, s. 209-216.

Bielińska E.J., 2006, Charakterystyka ekologiczna gleb ogrodów działkowych z terenów zurbanizowanych, ,Journal of Research and Applications in Agricultural Engineering", 51(2), s. 13-16.

Bielińska E.J., Mocek-Płóciniak A., 2010, Impact of ecochemical soil conditions on selected heavy metals content in garden allotment vegetables, „Polish Journal of Environmental Studies", 19(5), s. 895-900.

Chodak T., Szerszeń L., Kabała C., 1995, Metale ciężkie w glebach i warzywach ogródków działkowych Wroctawia, Zeszyty Problemowe Postępów Nauk Rolniczych, nr 418, s. 291-298.

Hursthouse A., Tognarelli D., Tucker P., Marsan F.A., Martini C., Madrid L., Madrid F., Diaz-Barrienthos E., 2004, Metal content of surface soils in parks and allotments from three European cities: initial pilot study results, „Land Contaminatoin \& Reclamation", 12(3), s. 189-197.

Jankiewicz B., Kobyłecka J., Ptaszyński B., Turek A., 2004, Determination of bioavailable forms of heavy metals in the soils from selected allotment gardens in Łódź, „Chemia i Inżynieria Ekologiczna”, 11(9), s. 907-913.

Jankiewicz B., Ptaszyński B., Turek A., 1999, Spectrometric determination of Copper (II) in samples of soil from selected allotment gardens in Lodz, „Polish Journal of Environmental Studies", 8(1), s. 35-38.

Jankiewicz B., Ptaszyński B., Wieczorek M., 2000, Spectrometric determination of Cadmium (II) in soils of allotment gardens in Lodz, ,Polish Journal of Environmental Studies", 9(2), s. 83-86.

Kabata-Pendias A., Piotrowska M., Motowicka-Terelak T., Maliszewska-Kordybach B., Filipiak K., Krakowiak A., Pietruch C., 1995, Podstawy oceny chemicznego zanieczyszczenia gleb - metale ciężkie, siarka $i$ WWA, Biblioteka Monitoringu Środowiska, Warszawa, $34 \mathrm{~s}$.

Lis J., Pasieczna A., 1998, Atlas geochemiczny aglomeracji łódzkiej, część I, Państwowy Instytut Geologiczny, Warszawa, $72 \mathrm{~s}$.

Mocek A., Owczarzak W., Tyksiński W., Kaczmarek K., 1995, Metale ciężkie w glebach ogródków działkowych Polkowic, Zeszyty Problemowe Postępów Nauk Rolniczych, nr 418, s. 299-304.

Moir A.M., Thornton I., 1989, Lead and cadmium in urban allotment and garden soils and vegetables in the United Kingdom, „Environmental Geochemistry and Health”, 11(3-4), s. 113-119.

Niedbała M., Smolińska B., 2011, Monitoring zanieczyszczenia gleb miejskich miasta Łodzi wybranymi pierwiastkami śladowymi w latach 2008-2010, Ochrona Środowiska i Zasobów Naturalnych, nr 49, s. 247-255.

Niewiadomski A., 2013, Struktura $i$ znaczenie terenów zieleni $w$ Łodzi na tle dużych ośrodków miejskich w Polsce, „Acta Universitatis Lodziensis, Folia Geographica Physica", 12, s. 33-47. 
Niewiadomski A., 2014, Oddziaływanie górnictwa siarki na środowisko przyrodnicze na przykładzie KiZPS „Siarkopol” w Machowie, Kaliskie Tow. Przyjaciół Nauk. Kalisz, $116 \mathrm{~s}$.

Ociepa-Kubicka A., Ociepa E., 2012, Toksyczne oddziaływanie metali ciężkich na rośliny, zwierzęta i ludzi, „Inżynieria i Ochrona Środowiska”, 15(2), s. 169-180.

Oleśków B., 2007, Ocena stopnia zanieczyszczenia gleb metalami ciężkimi ogródków dziatkowych rejonu Wrocławia, „Ochrona Środowiska i Zasobów Naturalnych”, 31, s. $121-125$.

Świercz A., Sykała E., 2009, Charakterystyka jakości gleb ogrodów działkowych w Kielcach, „Ochrona Środowiska i Zasobów Naturalnych”, 40, s. 103-111.

Wegelin T., Jenka B., Etter R., 1995, Heavy metals in soils and plants of allotment gardens in the city of Zurich (Switzerland), „Soil \& Environment”, 5, s. 269-270.

Węglarzy K., 2007, Metale ciężkie - źródta zanieczyszczeń $i$ wptyw na środowisko, „Wiadomości Zootechniczne”, 45(3), s. 31-38.

Właśniewski S., Hajduk E., 2012, Akumulacja kadmu $w$ glebach $i$ wybranych warzywach uprawianych w ogrodach dziatkowych Rzeszowa, „Roczniki Gleboznawcze”, 63(1), s. $55-60$.

Wójcikowska-Kapusta A., 2007, Wybrane właściwości fizykochemiczne i chemiczne gleb ogródków działkowych, „Zeszyty Problemowe Postępów Nauk Rolniczych”, 520, s. 547-554.

Ziomek J., Iwańcz T., Laskowski S., 2009, Geologia i gleby, [w:] Liszewski S. (red.), Atlas miasta Łodzi, [online], <http://www.mapa.lodz.pl/atlas/atlas.htm>.

\section{SUMMARY}

The paper presents the research results of physical and chemical soil properties of allotment gardens in Łódź. 15 soil samples taken from humus layers were analyzed. In the selection of most allotment gardens the vicinity of major transport routes and industrial plants were accounted. Characterisation of the soil substrate was made taking into account the geological factors influencing the genetic and qualitative value of soil especially for agricultural production. Authors drew attention to the variability of soil properties and compared the obtained results to other Polish cities. It was found that the tested soils show high sorption capacities and low in comparison with other cities, degree of heavy metal (cadmium, chromium and copper) pollution. They also highlighted the significant production potential of soils of allotment gardens.

Keywords: allotment gardens, hortisols, soil properties, Łódź 